\title{
Literature Study of Understanding the Physical Concepts of Straight Motion Materials Using the Gasing Method
}

\author{
Erwin Prasetyo $^{1 *}$, Budi Jatmiko ${ }^{2}$, and Adi Jufriansah ${ }^{3}$ \\ ${ }^{1,3}$ Department of Physics Education, IKIP Muhammadiyah Maumere \\ Jl. Jendral Sudirman, Sikka, Nusa Tenggara Timur, Indonesia \\ ${ }^{2}$ Department of Physics Education, Universitas Negeri Surabaya \\ Jl. Lidah Wetan, Lakarsantri, Surabaya, Jawa Timur, Indonesia \\ *Email: wintyo212@gmail.com
}

\begin{tabular}{|c|c|}
\hline Article Info & \multirow{3}{*}{$\begin{array}{l}\text { Not all physics concepts must be understood and mastered by deriving formulas } \\
\text { through differential or integral techniques. Mechanics, for example, can be } \\
\text { understood with simple logic without formulas, variables, and numbers. The fun } \\
\text { method, or known as the GASING method, is a science learning method that has been } \\
\text { offered by Yohanes Surya since 1996. This method offers fun learning activities for } \\
\text { students. This research is a literature review of several books and research articles } \\
\text { related to learning physics science using top methods. It turns out that with the } \\
\text { spinning method, the concepts of velocity and acceleration in straight motion material } \\
\text { can be understood easily and can solve some physics problems about straight motion } \\
\text { without complicated physics formulas. All these physics problems are solved by } \\
\text { simple logic and expressed in words. }\end{array}$} \\
\hline $\begin{array}{l}\text { Article History } \\
\text { Received May 31, } 2020 \\
\text { Accepted Dec 01, } 2020 \\
\text { Published Dec 31, } 2020\end{array}$ & \\
\hline $\begin{array}{l}\text { Keywords: } \\
\text { Gasing method } \\
\text { Mechanics concepts } \\
\text { Fun learning }\end{array}$ & \\
\hline o cite this article: & ncepts of \\
\hline
\end{tabular}

\section{Introduction}

One of the demands of learning in the 21 st century is how students can improve their ability to think at a higher level, namely critical and creative [1,2], which is Bloom's revised Anderson taxonomy enters cognitive levels: C4 (analyzing), C5 (evaluating) and C6 (creating) [3-6]. On the other hand, learning must simultaneously encourage students. The teacher must convey the material taught correctly and efficiently understood to understand the concept quickly and is very engrossed and fun solving daily life problems.

Many students consider physics as a scary subject [7]. Physics is regarded as a complicated subject to study [8-9] because physics is always associated with memorizing numbers and formulas. Not all material in physics must be understood by deriving and memorizing formulas. However, some materials can be understood using simple logic. Another thing students do not like about physics is teaching methods that are less fun and teacher competencies that are not by their educational background.

For example, straight motion material should not be studied by memorizing velocity, distance, and time formulas in regular straight motion material and initial velocity formulas. Final velocity, time, and acceleration in straight-motion material change irregularly. With the Gasing method, understanding the material of straightline motion and irregular straight-line motion changes in everyday life does not have to derive and memorize formulas [10-11]. However, it can use simple logic without complicated mathematics [12-13].

Based on research conducted by schools assisted by the Yohannes Surya Team at Surya Institut, that interest and skills of high-level thinking on the understanding of physical science concepts using a top method (Gampang, Asyik, and Menyenangkan) [14]. The results of this study indicate that: 1) There is a significant difference in conceptual understanding between groups of students who use conventional learning methods and groups of students who use top learning; 2) There is a significant difference in conceptual understanding between groups of students who have high interest and groups of students who have low interest, and 3) There is a significant interaction effect between the implementation of the Gasing method with high and low-interest rates on high level thinking on conceptual understanding [15-18]. From these results, this research aims to obtain information on understanding the concepts of physical science lessons on the material of motion with fun and fun (Gasing).

\section{Method}

This study focuses on analyzing the literature of journals and books to find out what will be learned from a theory, findings, and references used as a basis for reviewing and describing ideas from previous literature. Researchers provide understanding and explanation so 
that readers can understand correctly. This research uses descriptive analysis, namely the details of structured secondary data obtained based on a philosophical and pedagogical approach. This approach was chosen to get new concepts from the development of existing theories. The selection of data sources is based on four aspects, namely credential evidence, the objectivity of ideas, degree of trust, and value of the contribution. This research's primary source is the idea put forward by Prof. Yohannes Surya in 1966, then managed to break the world record in 2015 with the Surya Institute. This study's data analysis examines the documentation data using bibliographic annotation analysis by looking at the reference source's identity, simple conclusions, and the formulated problem's contribution.

\section{Results and Discussion}

The Gasing method is one part of the direct learning method. The stages are fun or the syntax of the direct learning method, according to Joyce and Weil [19], as follows:

1. Orientation

Before teaching new material, the teacher needs to provide a direction and learning framework to understand the subject matter more quickly. The forms of orientation can be:

a. Preliminary activities to assess relevant student knowledge and understanding,

b. Discuss or inform the objectives of the lesson,

c. Explain/direction of the activities carried out,

d. Explain the material or concepts involved, and the activities carried out during the learning process, and

e. Inform the learning framework.

2. Presentation

At this phase, the teacher can discuss the material in the form of concepts and skills. Presentation of material can be:

a. Present the material in small parts to make it easier and shorten the time for students to understand,

b. Giving examples of concepts,

c. The modeling or demonstration of skills employing demonstrations or explanations of work steps on the task, and

d. Re-explain difficult matters.

3. Structured exercise

In this phase, the teacher accompanies students to work on practice questions. Providing feedback, reinforcing, and assessing student understanding is an essential role for teachers in this phase.

Guided exercise. In this phase, the teacher provides opportunities for students to practice concepts or skills.

4. The guided exercise is also good to be used by teachers to assess/assess students' ability to do their work.
In this phase, the teacher monitors and guides students if needed.

5. Independent training

In this phase, students carry out training activities independently. Students can go through this stage if they have mastered the work task stages of $85-90 \%$ at the training guidance stage.

The Gasing method is oriented towards a deductive approach and emphasizes the mastery of concepts and student behavior changes. The characteristics of the Gasing method are direct and skill transformation, goaloriented learning, structured learning materials, structured learning environment, and structured by teachers [7],[20].

\section{Gasing Learning Strategies}

Gasing is an alternative method of learning physics [21-23]. Gasing learning strategy teaches how to think like a physicist in solving physics problems with a logical approach and almost no formulas [24]. Because this Gasing learning strategy uses ordinary logic methods based on the basic concepts of physics and necessary mathematical calculation abilities, including adding, less, divide, and times so that students can work on problems quickly and correctly. So, Gasing learning strategies train how to express or solve various physics problems with the logic of words, while formulas can adjust afterward [25-28].

According to the results of research conducted by Prof. Yohanes Surya, to make physics easy, fun, and enjoyable (Gasing), some things to note are:

1. Avoid complicated math calculators; use more straightforward math.

2. Take advantage of the correct understanding of physics concepts and emphasize logic rather than using derivative formulas.

3. Use integers and easy numbers such as 1,2 , or 10 when teaching concepts through sample problems. Do not use decimals or fractions so that students' concentration is not distorted from physical solving to math solving.

4. Promote direct dialogue with students about newly taught physics concepts. Ask students to express their opinions to solve problems related to the concept given.

5. Expand physics experiments and demonstrations so that each student enjoys physics's fun, and students can feel that physics is entertaining.

The implementation of the Gasing learning strategy is divided into several stages [29-31], namely:

1. Simple Dialogue

Dialogue is a form of two-way communication. In this case, those involved are teachers and students. According to the connectionism learning theory or bond hypothesis put forward by Thorndike, Learning is the formation or strengthening of the relationship between S (stimulus) and R (response) [32], so that between $\mathrm{S}$ and $\mathrm{R}$, a relationship (bond) occurs, which gets tighter if often trained. Thanks to the exercise of 
the relationship between $\mathrm{S}$ and $\mathrm{R}$ must provide "satisfaction." A sense of satisfaction is reinforcement or reinforcement. Regarding the relationship between $\mathrm{S}$ and $\mathrm{R}$, Thorndike discovered various laws. Some of them are:

\section{a. Law of effect}

The relationship between $\mathrm{S}$ and $\mathrm{R}$ increases when accompanied by pleasure or satisfaction but becomes weak or disappears when accompanied by displeasure. Happiness causes the secretion of hormones in synapses, so the relationship becomes smooth. Therefore praising and encouraging students (feeling happy) is better in teaching than punishing or reproaching (feeling displeased).

b. Law of exercise or law of use and law of disuse The relationship between $\mathrm{S}$ and $\mathrm{R}$ increases tightly if often practiced or used and decreases if it disappears or is never used. It needs to be held a lot of practice and habituation.

c. Law of multiple responses In a problematic situation where the right response does not appear immediately, individuals conduct various kinds of experiments that initially did not work. Still, in the end, they might give the correct answer. This procedure is called "trial-anderror," trial and error while making mistakes.

d. Law of assimilation or law of analogy A person can adjust or respond according to new situations, which are slightly different from those that already exist but contain the same elements (identical elements).

From the four laws above, it can be concluded that the relationship between $\mathrm{S}$ (stimulus) and $\mathrm{R}$ (response) is significant and interrelated in the learning process to achieve the expected learning outcomes.

2. Imagine or fantasize.

Imagination or fantasy in the education process is essential for students to have [33,34], but teachers in teaching and learning activities largely ignore this aspect. Imagination is essential because, with imagination, the students will give birth to a concept, creativity, innovation, and actual behavior in their lives $[35,36]$. In other words, imagination is more important than knowledge.

3. We are presenting relevant problem examples.

Training or training is the right way of teaching to instill certain habits. This method can also obtain a student's mastery, accuracy, opportunity, and skills to strengthen students' mathematical mastery. In this exercise, students only practice using simple mathematical logic, namely addition, subtraction, multiplication, and division.

4. We are presenting material in depth.

By giving physical meaning to each physics magnitude, students are expected to know what is experienced by each object in the item.

5. Stage five: Give a variety of questions.
Assignments or recitation is a way of presenting learning material in giving specific tasks to carry out learning activities, and are accountable for them. Assignments given by the teacher can deepen the learning material and can also check the material that has been learned. The task can stimulate students to learn both individually and in groups actively.

According to Ambotaang and Rafiqah [29], the Gasing learning strategy's complete stages can be seen in the Table 1.

Table 1. Stages of learning with the Gasing method

Stages of the
Gasing
Method

\begin{tabular}{ll}
\hline Simple & The teacher starts learning by having a \\
dialogue & simple dialogue with students about the \\
& material to be discovered. Students are \\
& expected to give their opinions from \\
this dialogue, resulting in a close & relationship between S and R. \\
& The teacher helps students to imagine \\
Imagine or & events related to the material being \\
fantasize & studied. \\
Present & To strengthen students mastery of \\
relevant & mathematics, the teacher provides \\
examples of & exercises for simple questions that only \\
problems & use mathematical formulas besides \\
& subtraction, multiplication, \\
division. & The teacher gives physical meaning \\
Presenting & after the student feels able to do all the \\
material in & simple questions earlier. \\
depth & The teacher returns to give questions \\
Give variety & but is more varied, and these questions \\
question & can be in the form of story questions. \\
&
\end{tabular}

On the other hand, Ambotaang and Rafiqah [29] Slavin put forward seven steps regarding the learning top.

1. Explain the purpose and orientation of the lesson to students. At this phase, the teacher conveys the things learned and student performance.

2. Review the planned knowledge and skills. At this phase, the teacher asks questions to explore the knowledge and skills students already have.

3. They are delivering subject matter based on the concept of basic understanding. In this phase, the teacher presents the material, shows information, provides examples, demonstrates concepts, etc.

4. Carry out guidance. Guidance is done by asking questions to assess students' level of understanding and correcting misconceptions.

5. Provide opportunities for students to practice. At this phase, the teacher facilitates students to implement skills and use new knowledge individually and collectively.

6. Assess students' performance and provide feedback. The teacher reviews students' things, gives feedback on students' correct responses, and repeats the necessary skills. 
7. It provides independent practice starting from concept questions to story problems. At this phase, the teacher needs to provide independent assignments to students to enrich their understanding of the material that has been studied.

\section{Discussion of the Concept of Straight Motion}

Understanding the concept of physics in the concept of uniform speed can be taught by introducing it by collecting the characteristics of uniform speed, explaining the concept of speed and acceleration, providing examples of concepts, presenting concepts of various forms and multiple-choice descriptions, and developing an understanding by providing examples of phenomena for solving the problem. Based on this description, learning activities are fundamental activities. That is, the learning process experienced by students affects the success of achieving educational goals. A person's view of learning will influence his actions related to learning [37].

The following are the top method for understanding speed, acceleration for uniform speed, and uniform acceleration. Some questions and solutions were taken from the physics book participant Gasing Yohannes Surya [38].

1. The uniform speed

\section{a. Simple dialogue}

The teacher starts learning by having a simple dialogue with students about the concept of speed. The speed of an object expresses how far the object moves in one unit of time. For example:

1) An object moves as far as 5 meters in 1 second. It can be said that the object is moving at a speed of 5 meters per second, or it can be written five $\mathrm{m} / \mathrm{s}$.

2) Bicycles move as far as $10 \mathrm{~km}$ in 1 hour, so it can be said that the bicycle is moving at a speed of $10 \mathrm{~km}$ per hour, or can be written 10 $\mathrm{km} /$ hour.

b. Imagine or fantasize

The teacher helps students to imagine the events that are related to regular straight motion material, for example, given a story problem;

Problem: An object moves at $3 \mathrm{~m} / \mathrm{s}$ and travels 18 meters; how much time will it take?

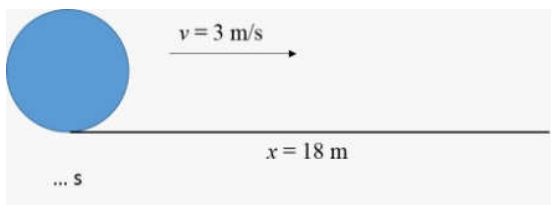

Settlement:

1) According to the concept of speed, the meaning of $3 \mathrm{~m} / \mathrm{s}$ is that every 1 -second objects travel a distance of 3 meters, or each distance of 3 meters takes 1 second, 6 meters takes 2 seconds, and so on.

2) Then the distance of 18 meters takes 6 seconds c. Present relevant problem examples

The teacher gives exercises in the form of simple problems that only use mathematical formulations in addition, subtraction, multiplication, and division.

Problem: There are two objects, A and B, facing each other 25 meters apart. The velocity of each object is $3 \mathrm{~m} / \mathrm{s}$ and $2 \mathrm{~m} / \mathrm{s}$. When and where do the two objects meet (measured from $\mathrm{A}$ )?

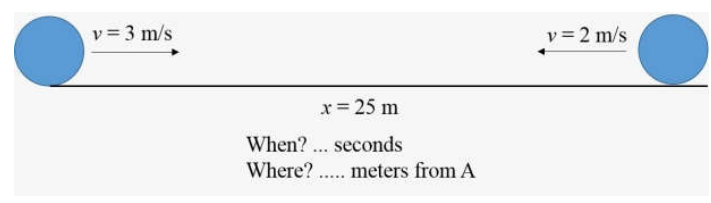

Settlement:

1) According to speed's concept, Object A moves at a speed of $3 \mathrm{~m} / \mathrm{s}$, meaning that every 1 second, the object travels a distance of 3 meters.

2) While object $B$ moves at a speed of $2 \mathrm{~m} / \mathrm{s}$, meaning that every 1 second, the object travels a distance of 2 meters.

3) Logically, every second object A advances 3 meters, and object $\mathrm{B}$ advances 2 meters, then every 1 second, both objects add near 5 meters, 2 seconds add near 10 meters, and so on.

4) So for a distance of 25 meters, it takes 5 seconds.

5) So when did Objects A and B meet? Answer at 5 seconds.

6) To find the measured position measured from object A, still, with logic, Object A moves at a speed of $3 \mathrm{~m} / \mathrm{s}$, meaning that every 1 second, the object travels a distance of 3 meters, 2 seconds travels a distance of 6 meters, and so on. So for 5 seconds, a distance of 15 meters.

7) So, where do the two objects meet measured from object A? Answer at a distance of 15 meters from object $\mathrm{A}$

d. Presenting material in depth

The teacher gives physical meaning after the student feels able to do all the simple questions earlier. The solution to the problem above is not with a complicated physics formula.

e. Give a variety of questions.

The teacher returns to give questions but is more varied, and these questions can be in the form of story questions.

Problem: It is known that two objects, A and B, chase each other, where object A with a speed of 5 $\mathrm{m} / \mathrm{s}$ chases object B, which has a speed of $4 \mathrm{~m} / \mathrm{s}$. If the two objects were initially separated by $5 \mathrm{~m}$, when and where (from position A) did object $\mathrm{A}$ meet object B?

Settlement:

1) By the concept of Speed, Object B moves at a speed of $4 \mathrm{~m} / \mathrm{s}$, meaning that every 1 - 
second object B moves forward from $\mathrm{A}$ as far as 4 meters.

2) Object $A$ moves at a speed of $5 \mathrm{~m} / \mathrm{s}$, meaning that every 1-second, object A moves toward object B as far as 5 meters.

3) The logic: every 1-second object, Object B moves away from object $\mathrm{A}$ as far as 4 meters and object A approaches object B 5 meters, then every 1 -second object $\mathrm{A}$ adds closer to object B 1 meter, 2 seconds adds near 2 meters, and so on. Alternatively, every 1 meter takes 1 second, so 5 meters takes 5 seconds.

4) So the time needed for object $\mathrm{A}$ to chase object $\mathrm{B}$ is 5 seconds.

2. Uniform acceleration

a. Simple dialogue

The teacher starts learning by having a simple dialogue with students about the Acceleration concept material.

1) Acceleration means that the object experiences a regular Speed increase every 1 second.

2) For an example of a moving object with an acceleration of $2 \mathrm{~m} / \mathrm{s}^{2}$, it means that every object has a different speed of $2 \mathrm{~m} / \mathrm{s}$.

b. Imagine or fantasize

The teacher helps students to imagine about the events related to the material of irregularly moving a straight motion, for example, given a story problem;

Problem: An object is initially stationary, accelerated with an acceleration of $4 \mathrm{~m} / \mathrm{s}^{2}$ for 2 seconds. How great is the speed?

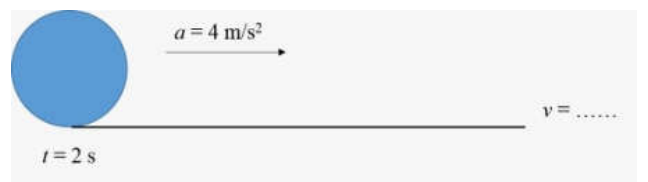

Settlement:

According to the acceleration concept, a moving object with an acceleration of $4 \mathrm{~m} / \mathrm{s}^{2}$ is equal to 4 $(\mathrm{m} / \mathrm{s}) / \mathrm{s}$, which means that every 1 second, the object's velocity increases by four $\mathrm{m} / \mathrm{s}, 2$ seconds the speed becomes $8 \mathrm{~m} / \mathrm{s}$, and so on. Because the initial speed is $0 \mathrm{~m} / \mathrm{s}$, the final speed is eight $\mathrm{m} / \mathrm{s}$.

c. Present relevant problem examples

The teacher gives exercises in simple problems that only use mathematical formulations besides, subtraction, multiplication, and division.

Question: An object initially moves at a speed of 4 $\mathrm{m} / \mathrm{s}$, then accelerated with an acceleration of 2 $\mathrm{m} / \mathrm{s}^{2}$ for 3 seconds. How great is the final speed?

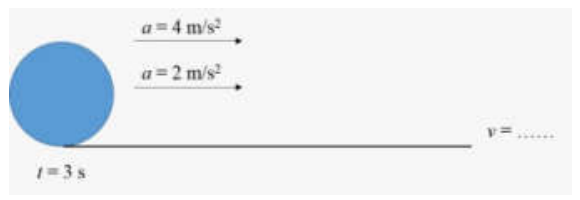

Settlement:

1) According to the acceleration concept, moving objects are accelerated with an acceleration of $2 \mathrm{~m} / \mathrm{s}^{2}$ equals $2(\mathrm{~m} / \mathrm{s}) / \mathrm{s}$, which means that every 1 second, the object's velocity increases by two $\mathrm{m} / \mathrm{s}, 2$ seconds the speed becomes four $\mathrm{m} / \mathrm{s}$, and so on. Then for 3 seconds, the speed becomes six $\mathrm{m} / \mathrm{s}$.

2) Because the initial speed is four $\mathrm{m} / \mathrm{s}$, the final speed is ten $\mathrm{m} / \mathrm{s}$.

d. Presenting material in depth.

The teacher gives physical meaning after the student feels able to do all the simple questions earlier. The solution to the problem above is not with a complicated physics formula.

e. Give a variety of questions.

The teacher returns to give questions but is more varied, and these questions can be in the form of story questions.

Problem: A move with an initial speed of $2 \mathrm{~m} / \mathrm{s}$ and then accelerated for 4 seconds so that the final speed is four $\mathrm{m} / \mathrm{s}$; what are the magnitude of the acceleration and the distance of the object?

Settlement:

1) From the initial Speed of $2 \mathrm{~m} / \mathrm{s}$ and the final Speed of $4 \mathrm{~m} / \mathrm{s}$ means, the object has increased speed by two $\mathrm{m} / \mathrm{s}$ for 4 seconds or means that every 1 second, the speed increases by $1 / 2 \mathrm{~m} / \mathrm{s}$ so that the acceleration of the object can be written as $1 / 2(\mathrm{~m} / \mathrm{s}) / \mathrm{s}$ equal to $1 / 2 \mathrm{~m} / \mathrm{s}^{2}$.

2) So the acceleration of the object is: $1 / 2 \mathrm{~m} / \mathrm{s}^{2}$

3) From the initial Speed of $2 \mathrm{~m} / \mathrm{s}$ and the final Speed of $4 \mathrm{~m} / \mathrm{s}$, the Average Speed of the object is $3 \mathrm{~m} / \mathrm{s}$, which means that every 1 second, the object takes a distance of 3 meters, 2 seconds takes a distance of 4 meters, and so on.

4) Then for 4 seconds, the object traveled a distance of 12 meters. So the object's distance is 12 meters.

With the above stages, students are expected to master the concept correctly and be able to solve physics problems without using existing formulas. This is in line with the views of Jatiutoro et al. [39] and Irawan [24]. The study results concluded that the Gasing method could be implemented as a learning method for students; this is according to research by Rafiqah, Ambotaang in class VIII [29].

According to Prahmana and Suwasti [40], Math Gasing made a real contribution to students' understanding of the concept of division operations. Moreover, the learning method can improve motivation and student learning outcomes, according to research by Cahya Dinata et al. in class IX A SMP Muhammadiyah 1 Banjarmasin [41].

The Gasing method by setting the learning cycle increases the average score of scientific attitudes and problem-solving abilities. Besides, students' responses to 
the top method's application with the 7E learning cycle setting are in a positive category $[42,43]$. Similarly, according to Jatiutoro et al. [39], there is the effect of Problem Solving Learning with the Guided Inquiry method and the Gasing Method on students' cognitive and psychomotor learning achievements.

These various facts indicate that the learning strategy of the Gasing (Gampang, Asyik, and Menyenangkan) method can be applied to physics subjects, including movement material, and is useful in increasing learning outcomes, learning achievement, and learning motivation.

\section{Conclusion}

The top method stages are almost the same as the direct learning method by avoiding understanding physical concepts with complex formulas and avoiding solving physics problems with complicated mathematical calculations.

The discussion of the concept of straight motion, both irregular straight motion and straight motion change irregularly through the top method stages, is straightforward to understand without having to memorize the speed and acceleration equations in regular straight motion and straight changing irregular motion.

In addition to physics being easily understood, the top method can increase learning motivation, improve learning outcomes, and student achievement.

\section{References}

[1] C. Kivunja, "Teaching Students to Learn and to Work Well with 21st Century Skills: Unpacking the Career and Life Skills Domain of the New Learning," Int. J. High. Educ., vol. 4, no. 1, pp. 1-11, 2015.

[2] M. Claro et al., "Assessment of 21st Century ICT Skills in Chile: Test Design and Results from High School Level Students," Comput. Educ., vol. 59, no. 3, pp. 1042-1053, Nov. 2012.

[3] T. S. Yen and S. H. Halili, "No Title," Online J. Distance Educ. e-Learning, vol. 3, no. 2, pp. 41-47, 2015.

[4] F. Barari, N., RezaeiZadeh, M., Khorasani, A., \& Alami, "Designing and Validating Educational Standards for ETeaching in Virtual Learning Environments (VLEs), Based on Revised Bloom's Taxonomy," Interact. Learn. Environ., pp. 1-13, 2020.

[5] N. Kiesler, "Towards a Competence Model for the Novice Programmer Using Bloom's Revised Taxonomy-An Empirical Approach," in In Proceedings of the 2020 ACM Conference on Innovation and Technology in Computer Science Education, 2020, pp. 459-465.

[6] H. Ichsan, I. Z., \& Rahmayanti, "HOTSEP: Revised Anderson's Taxonomy in Environmental Learning of COVID-19," Eur. J. Educ. Res., vol. 9, no. 3, pp. 1257$1265,2020$.

[7] E. K. H. C. Angell, Ø. Guttersrud, "Physics: Frightful, but Fun Pupils' and Teachers' Views of Physics and Physics Teaching," Sci. Educ., vol. 88, no. 5, pp. 683-706, 2004.

[8] A. Poynter and D. Tall, "What Do Mathematics and Physics Teachers Think That Students Will Find Difficult? A Challenge to Accepted Practices of Teaching," in Proceedings of The Sixth British Congress of Mathematics Education held at the University of Warwick, 2005, pp. 128-135.

[9] S. Mekonnen, "Problems Challenging the Academic Performance of Physics Students in Higher Governmental Institutions in the Case of Arbaminch, Wolayita Sodo, Hawassa and Dilla Universities," Nat. Sci., vol. 06, no. 05, pp. 362-375, 2014.

[10] Allivna and Mundilarto, "Developing Instrument Assessment of Student's Process Skills in Physics Learning Based on Local Wisdom," Int. J. Educ. Res. Rev., vol. 4, no. 4, pp. 489-495, 2019.

[11] C. Muliyati, D., Nurindrasari, M., Ervina, E., \& Rustana, "Student Worksheet Based on PhET Simulation for the Parabolic Motion: A Design Worksheet Using the PredictObserve-Explain Model," in In Prosiding Seminar Nasional Fisika (SNF), 2019, pp. 155-162.

[12] U. N. Sultonova, "Formation of Basic Competences for Students by Solving Problems in Physics," Eur. J. Res. Reflect. Educ. Sci., vol. 7, no. 11, pp. 107-114, 2019.

[13] L. A. Bloomfield, How Things Work: The Physics of Everyday Life. John Wiley \& Sons. 2015.

[14] E. Surya, Y., \& Pitowarno, "Robust Adaptive Proportional Derivative-Active Force Control for Unmanned Hexacopter," in In 2016 International Electronics Symposium, 2016, pp. 1-6.

[15] R. C. I. Prahmana, "The Hypothetical Learning Trajectory on Addition in Mathematics GASING," Southeast Asian Math. Educ. J., vol. 5, no. 1, pp. 49-61, 2015.

[16] A. Pramarista, "Learning Design on Whole Number Addition Using Gasing Method," in The First South East Asia Design/Development Research (SEA-DR) International Conference, 2013, pp. 1-19.

[17] J. H. Siregar, W. Wiyanti, N. S. Wakhyuningsih, and A. Godjali, "Learning the Critical Points for Addition in Matematika Gasing," J. Math. Educ., vol. 5, no. 2, pp. 1042-1053, Jul. 2014.

[18] R. Istiqomah, "Improving Senior High School Student's Creativity Using Discovery Learning Model in Islamic Senior High School 1 Jambi City," Eur. J. Multidiscip. Stud., vol. 3, no. 2, pp. 108-115, 2018.

[19] R. Joyce, M. Weil, and E. Calhoun, Models of Teaching, 9th ed. Boston: Pearson, 2015.

[20] N. M. D. Mustafa and M. F. T. Saearani, "Learning Strategies Based on the Approach of Modelling by the Coach in Internalization Process of Wau Bulan Folk Dance," Int. J. Acad. Res. Progress. Educ. Dev., vol. 8, no. 4, pp. 418-428, 2019.

[21] S. Fiun, "The Effect of the Mathematical GASING Method and Spatial Intelligence on Science Achievement," in Educational Technology to Improve Quality and Access on a Global Scale, Cham: Springer International Publishing, 2018, pp. 245-256.

[22] P. A. C. Dinata, D. Sastradika, and A. D. Safitri, "Implementation of Gasing Learning in ARCS Learning Strategy to Enhance Students' Motivation in 9th Grade of Indonesian Junior High-School," IJPTE Int. J. Pedagog. Teach. Educ., vol. 1, no. 2, pp. 245-256, Oct. 2017.

[23] L. F. Nuari, R. C. I. Prahmana, and I. Fatmawati, "Learning of Division Operation for Mental Retardations' Student through Math Gasing," J. Math. Educ., vol. 10, no. 1, pp. 127-142, Jan. 2019.

[24] N. W. Irawan, "Metode Gasing dengan Eksperimen untuk Meningkatan Hasil Belajar Fisika Konsep Mekanik Zat (Hukum Hooke) pada Peserta Didik Kelas X Multimedia SMK Negeri 2 Pati Semester Genap Tahun Ajaran 2014/2015," in SNPS Proceedings, 2015, pp. 394-405.

[25] I. G. Astawan and I. W. Mustika, "Meningkatkan 
Aktivitas dan Kemampuan Memecahkan Masalah melalui Pembelajaran Kuantum Teknik Fisika Gasing," $J$. Pendidik. dan Pengajaran, vol. 46, no. 2, pp. 136-146, Jan. 2013.

[26] M. A. Rusli, A. M. Yusuf, A. Azis, A. Purwanto, and J. Taruna, "Student's Physics Achievement through Gasing Physics Learning," in International Conference on Mathematics, Science, Technology, Education, and their Applications, 2016, pp. 460-465.

[27] Y. Purwari, "Pendekatan Saintifik dengan Metode Gasing pada Pembelajaran Fisika," JPGI (Jurnal Penelit. Guru Indones., vol. 5, no. 1, pp.1-7, May 2020.

[28] C. Muliyati, D., Nurindrasari, M., Ervina, E., \& Rustana, "Student Worksheet Based on PhET Simulation for Parabolic Motion: A Design Worksheet Using PredictObserve-Explain Model," in In Prosiding Seminar Nasional Fisika (SNF), 2019, pp. 155-162.

[29] Ambotaang and Rafiqah, "Efektivitas Metode Gasing Terhadap Pemahaman Konsep Materi Energi dan Perubahannya Peserta Didik SMP Negeri 4 Satap Batumenteng," J. Pendidik. Fis., vol. 3, no. 2, pp. 119123, 2015

[30] R. C. I. Prahmana and Y. S. Kusumah, "The Hypothetical Learning Trajectory on Research in Mathematics Education Using Research-Based Learning," Pedagogika, vol. 123 , no. 3, pp. 42-54, Sep. 2016.

[31] H. Hendriana, R. C. I. Prahmana, and W. Hidayat, "The Innovation of Learning Trajectory on Multiplication Operations for Rural Area Students in Indonesia," $J$. Math. Educ., vol. 10, no. 3, pp. 397-408, Aug. 2019.

[32] J. C. Horvitz, W. Y. Choi, C. Morvan, Y. Eyny, and P. D. Balsam, "A 'Good Parent' Function of Dopamine: Transient Modulation of Learning and Performance during Early Stages of Training," Ann. N. Y. Acad. Sci., vol. 1104, no. 1, pp. 270-288, Apr. 2007.

[33] Y. Hsu, C. Liang, and C.-C. Chang, "The Mediating Effects of Generative Cognition on Imagination Stimulation," Innov. Educ. Teach. Int., vol. 51, no. 5, pp. 544-555, Sep. 2014.
[34] N. A. Kovalenko and A. Y. Smirnova, "Self-Directed Learning through Creative Activity of Students," Procedia - Soc. Behav. Sci., vol. 166, no. 5, pp. 393-398, Jan. 2015.

[35] S. Broström, "A Dynamic Learning Concept in Early Years' Education: A Possible Way to Prevent Schoolification," Int. J. Early Years Educ., vol. 25, no. 1, pp. 3-15, Jan. 2017.

[36] J. D. Hoffmann and S. W. Russ, "Fostering Pretend Play Skills and Creativity in Elementary School Girls: A Group Play Intervention.," Psychol. Aesthetics, Creat. Arts, vol. 10, no. 1, pp. 114-125, Feb. 2016.

[37] Slameto, Belajar dan Faktor-Faktor yang Mempengaruhi. Jakarta: Rineka Cipta, 2010.

[38] Y. Surya, "Gasing Physics Participant Book," 2000. www.yohanessurya.com.

[39] P. Jatiutoro, W. Sunarno, and S. Soeparmi, "Pembelajaran IPA Fisika dengan Model Problem Solving Menggunakan Metode Inkuiri Terbimbing dan Metode Gasing Ditinjau dari Kemampuan Verbal dan Kemampuan Logika Matematika Siswa," J. Inkuiri, vol. 7, no. 1, pp. 133-142, 2018.

[40] R. C. I. Prahmana and P. Suwasti, "Local Instruction Theory on Division in Mathematics Gasing," J. Math. Educ., vol. 5, no. 1, pp. 133-142, Jan. 2014.

[41] P. A. C. Dinata, M. A. Jamal, and M. Mastuang, "Meningkatkan Motivasi dan Hasil Belajar Siswa dengan Menggunakan Metode Pembelajaran GASING (Gampang, Asyik, dan Menyenangkan) pada Siswa Kelas IX A SMP Muhammadiyah 1 Banjarmasin," Berk. Ilm. Pendidik. Fis., vol. 4, no. 2, pp. 161-172, Jul. 2016.

[42] A. E. Putra and P. Artawan, "Metode Gasing Berseting Siklus Belajar Meningkatkan Sikap Ilmiah dan Kemampuan Pemecahan Masalah," J. Wahana Mat. dan Sains, vol. 8, no. 1, pp. 47-60, 2014.

[43] P. G. Wartawan, "Metode Gasing dengan Setting Siklus Belajar 7E untuk Meningkatkan Sikap Ilmiah dan Kemampuan Pemecahan Masalah," in Proceedings Seminar Nasional FMIPA Undiksha V Tahun 2015, 2015, pp. $395-403$. 